\title{
A systematic review of policy approaches to dairy sector Greenhouse Gas (GHG) emission reduction
}

Article

Accepted Version

Creative Commons: Attribution-Noncommercial-No Derivative Works 4.0

York, L., Rymer, C. and Heffernan, C. (2017) A systematic review of policy approaches to dairy sector Greenhouse Gas (GHG) emission reduction. Journal of Cleaner Production, 172. pp. 2216-2224. ISSN 0959-6526 doi:

https://doi.org/10.1016/j.jclepro.2017.11.190 Available at https://centaur.reading.ac.uk/74096/

It is advisable to refer to the publisher's version if you intend to cite from the work. See Guidance on citing.

To link to this article DOI: http://dx.doi.org/10.1016/j.jclepro.2017.11.190

Publisher: Elsevier

All outputs in CentAUR are protected by Intellectual Property Rights law, including copyright law. Copyright and IPR is retained by the creators or other copyright holders. Terms and conditions for use of this material are defined in the End User Agreement.

www.reading.ac.uk/centaur 
Central Archive at the University of Reading

Reading's research outputs online 


\section{A systematic review of policy approaches to dairy sector Greenhouse Gas}

2 (GHG) emission reduction.

3 L. York ${ }^{1}$, C. Heffernan ${ }^{1, \text { a }}$, and C. Rymer ${ }^{2}$

$4 \quad{ }^{1}$ Livestock Development Group (LDG), Faculty of Life Sciences, University of Reading,

$5 \quad$ Reading $R G 66 A R, U K$

$6 \quad{ }^{2}$ Sustainable Agriculture and Food Research Division, Faculty of Life Sciences, University of

7 Reading, Reading RG6 6AR, UK

8 Current address: School of Veterinary Sciences, University of Bristol, Langford House,

9 Langford, Bristol, BS40 5DU

10 Corresponding author: Luke York. Email: luke_york@live.com.au

\section{Abstract}

12 The dairy sector is a significant source of anthropogenic greenhouse gas (GHG) emissions.

13 The increasingly robust emission inventories allow researchers to consider mitigation.

14 However, there is a gap in knowledge regarding the extent to which mitigation research has

15 been implemented as policy. The authors undertook a systematic a review of national-level

16 dairy policy of 23 countries broadly following Preferred Reporting Items for Systematic

17 Reviews and Meta-Analyses (PRISMA) protocols. The aim of the study was to identify international trends in dairy sector GHG emission reduction policy. Sampled countries included the 12 countries with the highest quantity of dairy sector enteric methane emission and 11 Annex I countries with the largest number of dairy cattle per capita. A total of 34 documents were collated containing 62 policies across five themes. Themes included: nutrition, manure, health, breeding and management. Thirty-one policies were identified for both the high emission nations and Annex I nations with the largest number of dairy cattle per capita. Nutrition based interventions account for $36 \%(n=11)$ of all policies identified for high emitting nations. Manure based interventions account for $48 \%(n=15)$ of all policies identified for Annex I nations with the largest number of dairy cattle per capita. Across the sample, policymakers favoured manure management strategies $(n=24)$, particularly anaerobic digestion which accounted for $21 \%(n=13)$ of all identified policies. Nutrition based mitigation strategies were also preferred $(n=17)$. Policies aimed at reducing sector size were 
largely ignored $(n=4)$. The results indicate that significant mitigation is unlikely as manure emissions are only a small portion of total dairy sector emissions. The study concludes that policymakers are selecting the less politically sensitive mitigation strategies at the cost of emission reduction.

Keywords: systematic review, cow, mitigation, climate change, global warming

\section{Introduction}

Livestock's Long Shadow (FAO, 2006) introduced the livestock sector as a significant source of global Greenhouse Gas (GHG) emissions. Although the initial estimate of GHG emissions (18\% of all anthropogenic GHG emission) (FAO, 2006) has been revised (see FAO, 2010) the publication gained traction within the scientific community, policymakers, and the general public. Since this time, the contribution livestock make to climate change (via GHG emissions) has received significant research interest. The dairy sector is the focal point of such research as it contributes an estimated $4 \%$ to total global anthropogenic GHG emissions (FAO, 2010).

Quantifications of emission from northern dairy systems (particularly intensive dairying) are considered increasingly robust. This has spurred emission mitigation research (e.g. Yan et al., 2010; Doole, 2014; Dutreuil et al., 2014). The less robust emission estimates from the global south have limited mitigation research. However, the need for mitigation remains as it is estimated that approximately $35 \%$ of the world's cattle are kept by smallholders in SubSaharan Africa and South-Asia alone (Oosting et al., 2014). Thus, effective emission reduction policy must be developed for the north and south to ensure mitigation can occur at a global scale.

However, over ten years since publication of Livestock's Long Shadow (FAO, 2006), it is unclear what policies have been implemented to reduce the contribution of the dairy sector to global GHG emissions. It is broadly accepted to be government's role to initiate policies that will reduce emissions. Yet, the challenge posed by such a task should not be underestimated as mitigation policy must exist alongside policy tasked with safeguarding food security and climate change adaptation.

The research community increasingly notes that achieving emission reductions from the livestock sector will be difficult without an overall reduction in sector size. For example, 
Webb et al., (2014) found that achieving a 20\% reduction in United Kingdom livestock sector GHG emissions was not possible without reducing output (or exporting emissions overseas). Similarly, reduced stocking rates were required to reduce emissions from the New Zealand dairy sector (Adler et al., 2013; Doole, 2014). For tropical livestock systems a reduced stocking rate is recommended as it will also deliver additional benefits (such as; improved output, and lowering other environment impacts) (Oosting et al., 2014). Yet, to implement policy tasked with reducing sector size will require significant political will. Thus, there is a gap in knowledge regarding the extent to which mitigation research has been implemented as policy.

The study explores this gap in knowledge by undertaking a systematic a review of nationallevel dairy policy of 23 countries. The aim of the study was to identify trends in dairy sector emission reduction policy. By examining trends across nations it becomes possible to identify which inventions are favoured by policymakers and the extent to which dairy sector emission reduction is likely at a global scale.

\section{Methods}

A systematic review of national-level dairy policy of 23 countries was undertaken broadly following Preferred Reporting Items for Systematic Reviews and Meta-Analyses (PRISMA) protocols (Liberati et al., 2009; Moher et al., 2009). PRISMA protocols (Liberati et al., 2009; Moher et al., 2009) represent a more robust adjunct to documentary analysis techniques. However, as the investigation did not examine "studies" as the PRISMA statement (a 27 item checklist) (Moher et al., 2009) was designed to investigate, not all components of the statement were relevant. Similarly, as the study did not examine clinical studies, metaanalysis techniques and the Cochrane approach were of limited use (Heffernan et al., 2012).

\subsection{Country selection}

84 The 12 countries with the highest levels of dairy sector enteric methane emission and the 12 Annex I countries with the largest number of dairy cattle per capita were selected for inclusion. The sampling of 12 countries under each approach ensured the sample was representative of global dairy policymaking. The 12 highest emitting countries account for $55 \%$ of all enteric methane emissions from dairy cattle. The 12 Annex I countries represent $29 \%$ of all Annex I countries. However, five Annex I countries were included amongst the 
91 countries (38\% of all Annex I countries) were included in the study. The complete sample of 23 countries contribute $59 \%$ of the total global dairy sectors enteric methane emissions.

93 Enteric methane emission was used to indicate dairy sector emissions as the majority of dairy 94 sector emissions are a result of enteric fermentation (FAO, 2006, 2010; Gerber et al., 2011; 95 Gerber et al., 2013). A large number of dairy cattle per capita was assumed to indicate that the dairy sector contributes a disproportionally large amount to the country's total GHG emissions (Garnaut, 2008). Annex I countries were targeted as it was expected that these countries would be more aggressive in their attempts to reduce dairy sector GHG emissions. Under the United Nations Framework Convention on Climate Change (UNFCCC), Annex I

100 countries have committed to reducing their GHG emissions to 1990 levels by the year 2000

101 (UNFCCC, 2014a).

102 The FAOSTAT database was used to identify those countries with large dairy sector enteric 103 methane emissions (FAO, 2013a). Data from the year 2013 was used as this was the most 104 recent data available. The countries with the highest emitting dairy sectors (via enteric fermentation) are shown in Table 1. Annex I countries were identified from the UNFCCC website (see UNFCCC, 2014b). The human and dairy cattle population size of each Annex I country was obtained from FAOSTAT (FAO, 2013b). The number of dairy cattle was divided by the human population in each Annex I country to determine the number of dairy cattle per capita (Table 1). The final sample was composed of a total of 23 countries as New

110 Zealand appeared under both sampling strategies. 
120 Table 1: The 12 countries with the highest enteric methane emitting dairy sectors and the 12 Annex I countries 121 with the largest number of dairy cattle per capita in 2013 according to FAOSTAT (FAO, 2013a, b).

\begin{tabular}{|c|c|c|c|}
\hline $\begin{array}{l}\text { Countries with the } \\
\text { highest enteric } \\
\text { methane emitting } \\
\text { dairy sectors }\end{array}$ & $\begin{array}{l}\text { Quantity of enteric } \\
\text { methane emitted by } \\
\text { dairy cows ( } \mathrm{Tg} \text { of } \\
\left.\mathrm{CH}_{4}\right)^{\mathrm{a}}\end{array}$ & $\begin{array}{l}\text { Annex I countries } \\
\text { with the largest } \\
\text { number of dairy } \\
\text { cattle per capita }\end{array}$ & $\begin{array}{l}\text { The number } \\
\text { of dairy cows } \\
\text { per capita }\end{array}$ \\
\hline India & 2.60 & New Zealand & 1.07 \\
\hline Brazil & 1.65 & Ireland & 0.25 \\
\hline $\mathrm{USA}^{\mathrm{b}}$ & 1.18 & Belarus & 0.16 \\
\hline Sudan & 0.83 & Lithuania & 0.11 \\
\hline China & 0.83 & Denmark & 0.10 \\
\hline Russia $^{b}$ & 0.77 & Netherlands & 0.10 \\
\hline Pakistan & 0.66 & Latvia & 0.08 \\
\hline Ethiopia & 0.50 & Luxembourg & 0.08 \\
\hline Germany $^{\mathrm{b}}$ & 0.50 & Estonia & 0.07 \\
\hline France $^{b}$ & 0.43 & Iceland & 0.07 \\
\hline New Zealand ${ }^{b}$ & 0.43 & Switzerland & 0.07 \\
\hline Colombia & 0.38 & Australia & 0.07 \\
\hline
\end{tabular}

${ }^{\mathrm{a}} \mathrm{Tg}$ of $\mathrm{CH}_{4}=$ Teragram of methane.

${ }^{\mathrm{b}}$ Countries with the highest enteric methane emitting dairy sectors which are also Annex I Parties to the United Nations Framework Convention on Climate Change.

\subsection{Policy collation}

128 Government department websites relevant to the dairy sector for each country were

129 examined. Only national level departments were searched. Websites were required to be in

130 English to ensure a uniform approach to the collection of data. Available translation tools

131 (specifically Google Translate ${ }^{\mathrm{TM}}$ ) did not have sufficient functionality to support a uniform

132 approach. Although the requirement for English language websites may be a potential source

133 of bias, a sampling strategy without uniformity also risks the creation of bias.

134 The focus on English language websites may also be a source of bias in countries where

135 English is a second language (e.g. Brazil, Ethiopia, Pakistan, and Colombia). Such countries 136 are unlikely to translate extensive policy documents into English. English language 
137 documents identified for these countries are likely a summarized version. This issue was

138 managed via the inclusion of National Communications to the UNFCCC and the requirement

139 for only an excerpt during data extraction (discussed below).

140 The departments searched within each country are shown in Table 2. As climate change and

141 dairy production can be a cross-cutting issue, the websites of the various environmental

142 departments were also included. The search was conducted over a period of one week (1 - 7

143 December 2014). Sudan and Russia were removed from the analysis as no English language

144 departmental website could be identified.

145 Departmental websites had a search function of some form located on the homepage.

146 However, there was no way to restrict searches to policy documents. Documents were located

147 manually (electronically) via the policy (or legislative) archive. Within the archive, policy

148 documents were primarily listed via hyperlink to a PDF file.

149 Document relevance was determined from the title of the document. The use of generalist

150 terms was expected to generate a representative sample (Scott, 1990; Whittaker, 2009; Duffy,

151 2010). Titles were examined for an explicit mention of "climate change", "global warming",

152 "mitigation", "adaptation", "dairy", and/or "livestock". The relevant documents were saved

153 (as a PDF) and retained within the sample for content screening. For example, the documents

154 of Pakistan were retrieved from the Ministry of Climate Change. On the Ministry's

155 homepage, the link "policies" was followed. A total of ten documents were listed. Two

156 document titles included the required keywords. These two documents were saved for content

157 screening.

158 The most recent National Communication to the UNFCCC was also procured from the

159 UNFCCC website (UNFCCC, 2014c, d) for each sampled country. This document was

160 considered indicative of the countries stance on achieving GHG emission reduction from the

161 dairy sector.

\subsection{Content screening}

163 Each document was reviewed as part of the content screening process. Within each document

164 the text word search function $(\mathrm{CTRL}+\mathrm{F})$ was used. The same keywords used to initially

165 identify documents (i.e. "climate change", "global warming", "mitigation", "adaptation",

166 "dairy", and/or "livestock") were again used to determine relevance within the text of each

167 document. However, the explicit mention of a key search term was insufficient to retain the 
168 document within the sample. Rather, the paragraph containing the search term was reviewed

169 for a specific description of a dairy sector mitigation strategy or methodology.

\subsection{Data extraction}

171 Data were extracted from the final sample of documents in the form of a precise excerpt

172 containing the mitigation strategy. The excerpt was copied from the document and placed

173 into a Microsoft Word document. It was necessary to record precise excerpts to ensure all

174 collated excerpts are reflective of the point in time in which the search was conducted. 


\begin{tabular}{|c|c|c|c|}
\hline Country & Website search locations & $\begin{array}{l}\text { Policy documents } \\
\text { collated }\end{array}$ & $\begin{array}{l}\text { Excerpts } \\
\text { collation }\end{array}$ \\
\hline India & $\begin{array}{l}\text { Government of India } \\
\text { Department of Animal Husbandry Dairying \& Fisheries } \\
\text { Department of Agriculture and Co-operation } \\
\text { Planning commission } \\
\text { National Dairy Development Board } \\
\text { Ministry of Environment and Forests } \\
\text { Second National communication to the UNFCCC }\end{array}$ & 3 & 6 \\
\hline Brazil & $\begin{array}{l}\text { Government of Brazil } \\
\text { Ministry of Agriculture, Livestock and Supply } \\
\text { Ministry of the environment } \\
\text { Second National communication to the UNFCCC }\end{array}$ & 2 & 1 \\
\hline USA & $\begin{array}{l}\text { United States Environmental Protection Agency } \\
\text { United States Department of Agriculture } \\
\text { The White House } \\
\text { Sixth National Communication to the UNFCCC }\end{array}$ & 3 & 3 \\
\hline China & $\begin{array}{l}\text { The State Council for the People's Republic of China } \\
\text { Ministry of Agriculture of the People's Republic of China } \\
\text { Second National communication to the UNFCCC }\end{array}$ & 1 & 7 \\
\hline Pakistan & $\begin{array}{l}\text { Ministry of Climate change } \\
\text { Ministry of national food security and research } \\
\text { Pakistan Agricultural Research Council } \\
\text { First National communication to the UNFCCC }\end{array}$ & 2 & 5 \\
\hline Ethiopia & $\begin{array}{l}\text { Federal Democratic Republic of Ethiopia Ministry of Foreign Affairs } \\
\text { Federal Democratic Republic of Ethiopia Ministry of Agriculture and Rural Development } \\
\text { First National communication to the UNFCCC }\end{array}$ & 1 & 6 \\
\hline Germany & $\begin{array}{l}\text { Federal Ministry of Food and Agriculture } \\
\text { Federal Ministry for the Environment, Nature Conservation, Building and Nuclear Safety (BMUB) } \\
\text { Sixth National Communication to the UNFCCC }\end{array}$ & 2 & 2 \\
\hline France & $\begin{array}{l}\text { Ministry of Agriculture, Agrifood, and Forestry } \\
\text { Ministry of Ecology, Sustainable Development and Energy } \\
\text { Sixth National Communication to the UNFCCC - abstract only }\end{array}$ & 1 & 1 \\
\hline
\end{tabular}


Colombia

Ministry for Primary Industries

Sixth National Communication to the UNFCCC

Ministry of Agriculture and Rural Development

Ireland

Oefolopment

Second National Communication to the UNFCCC - Executive summary

Department of Agriculture, Food and the Marine

Sixth National Communication to the UNFCCC

Belarus

Ministry of Agriculture and Food of the Republic of Belarus

Ministry of Natural Resources and Environmental Protection

Department of Veterinary and Food Control

President of the Republic of Belarus

Fifth National Communication to the UNFCCC

Lithuania

Ministry of Agriculture of the Republic of Lithuania

State Food and Veterinary Service

Denmark

Sixth National Communication to the UNFCCC

Ministry of Environment and Food

Danish Agriculture and Food Council

Ministry of Foreign Affairs Denmark

The Danish Ministry of Climate and Energy

Sixth National Communication to the UNFCCC

Netherlands

Ministry of Economic Affairs

Costructure and Environment

Sixth National Communication to the UNFCCC

Latvia

Ministry of Agriculture

Ministry of Environmental Protection and Regional Development

Sixth National Communication to the UNFCCC

Luxembourg Ministry of Agriculture, Viticulture and Consumer protection

Ministry of Sustainable Development and Infrastructure

Sixth National Communication to the UNFCCC

Estonia

Ministry of Agriculture

Ministry of Environment

Sixth National Communication to the UNFCCC

Iceland

Ministry of Fisheries and Agriculture

Ministry for the Environment and Natural Resources

Sixth National Communication to the UNFCCC 
Switzerland

Federal Office of Agriculture

The Federal Department of the Environment, Transport, Energy and Communications (DETEC)

Sixth National Communication to the UNFCCC

Department of Agriculture and Water resources

Department of the Environment

Sixth National Communication to the UNFCCC 
185 Following data extraction, the mitigation strategies were clustered together for further analysis. Grouping was determined by the emission reduction target (i.e. the component of the production system that the intervention targets to achieve a reduction in GHG emissions). The themes included nutrition, breeding, health, management, and manure. For example, Danish policy indicates that, "emissions could possibly be reduced by changing the feed given to cattle....” (pp. 45) (The Danish Government, 2013). This intervention was placed within the nutrition theme as it attempts to utilise nutritional pathways to reduce GHG emissions.

Any replicated (within country) policies were removed from the analysis at this stage.

194 Additionally, if a legislative or policy statement contained a number of different

195 interventions, each intervention was considered separately. For example, the Australian legislation, Regulation 3.28 identifies feed-based interventions that include five different feed additives (Commonwealth of Australia, 2014). Each additive was considered as a standalone intervention and placed into a theme accordingly. Ideally, the relationship between enteric and manure methane, and $\mathrm{N}_{2} \mathrm{O}$ would be a consideration of reduction interventions (Knapp et al., 2014). However, little evidence of this relationship was identified within the policy set. Similarly, there was no evidence of any potential additive effects of interventions. Thus, it was appropriate to consider interventions individually.

\subsection{Categorized via topic}

204 Due to the diversity of the interventions within each theme it was necessary to further categorize themes via topic. Interventions were sorted by their mode of action (i.e. how the intervention attempted to achieve a reduction in GHG). Those interventions which were seen to have a similar mode of action were grouped together. For example, Indian policy states, "conversion of high fibre fodder into silage and chaffing/chopping of such fodder would be encouraged” (pp. 21) (Government of India, 2013) whilst Dutch policy states, “...the better the digestibility, the lower the methane emissions." (pp. 72) (Ministry of Infrastructure and the Environment, 2013). Both statements suggest that improvements to the digestibility of feeds will be sought to reduce GHG emission. These two statements were grouped together under the topic of "improved digestibility". Figure 1 provides the schemata for the analysis. 
Figure 1: The schemata outlining the various steps conducted to collate national dairy policy from 23 countries. Only 23 countries were included as New Zealand appeared under both country sampling strategies. Brackets indicate the number of variables at each stage of the analysis. 


\section{Results}

239 A total of 62 policies were identified from the sampled countries (Table 3). India, China,

240 Ethiopia and Australia had the most number of policies identified. A total of six policies were

241 identified for each country. No mitigation policies could be identified for New Zealand and

242 Iceland.

243 Thirty-one policies were identified for both the high emission nations and Annex I nations

244 with the largest number of dairy cattle per capita. Nutrition based interventions account for

$24536 \%(n=11)$ of all policies identified for high emitting nations. Manure based interventions

246 account for $48 \%(n=15)$ of all policies identified for Annex I nations with the largest number

247 of dairy cattle per capita.

248 Table 4 indicates a difference in the number of policies identified from policy documents and

249 the number of interventions reported in National Communications to the UNFCCC. Annex I

250 countries with the largest number of dairy cattle per capita are under-reporting policy

251 attempts to reduce dairy sector emissions whilst high emission countries are slightly over-

252 reporting. However, there is variability between nations. For example, no policies to reduce

253 dairy sector emissions could be identified from the National Communications of India and

254 Australia. Yet, six policies were identified from national policy documents for both countries.

255 Conversely, six policies were identified from the National Communications of China and

256 Ethiopia. No policies were identified in national policy documents.

257 Table 5 compares the number of polices identified for sampled Annex I and non-Annex I

258 countries. Annex I countries account for $65 \%(n=15)$ of the countries sampled and provide

$25958 \%(n=36)$ of the policies identified. The majority $(n=18)$ of policies identified in Annex I

260 countries are manure based interventions. Non-Annex I countries demonstrate a broader

261 range of interventions compared Annex I countries. However, 42\% $(n=11)$ of the policies

262 identified in non-Annex I countries are focused on nutrition based interventions.

263 Across the sampled nations, Table 6 indicates that a range of nutrition based interventions

264 (total of 9 different interventions) are used by policymakers to mitigate dairy sector GHG

265 emissions. Anaerobic digestion is the most common mitigation policy selected by

266 policymakers. A total of $21 \%(\mathrm{n}=13)$ of all sampled policies focus on anaerobic digester

267 installation. Table 6 also indicates that anaerobic digestion is uniformly popular across nearly 
268 all nations. Breeding cows for higher genetic merit $(n=7)$ and covering of liquid manure

269 facilities $(n=5)$ both garner significant policy support internationally.

270

271 Table 3: The distribution of dairy sector greenhouse gas mitigation policies offered by policymakers from 21

272 countries categorized via theme. Russia and Sudan are not presented as no English language websites could be 273 located.

\begin{tabular}{|c|c|c|c|c|c|c|c|}
\hline & \multirow[t]{2}{*}{ Country } & \multicolumn{5}{|c|}{ Number of policy interventions identified in each theme } & \multirow[t]{2}{*}{ Total number } \\
\hline & & Nutrition & Breeding & Health & Management & Manure & \\
\hline \multirow{11}{*}{$\begin{array}{l}\text { Countries with } \\
\text { the highest } \\
\text { enteric } \\
\text { methane } \\
\text { emitting dairy } \\
\text { sectors }\end{array}$} & India & 5 & & & & 1 & 6 \\
\hline & Brazil & & & & & 1 & $\mathbf{1}$ \\
\hline & $\mathrm{USA}^{\mathrm{a}}$ & & & & & 2 & 2 \\
\hline & China & 1 & 1 & 1 & 2 & 1 & 6 \\
\hline & Pakistan & 2 & 2 & & & 1 & 5 \\
\hline & Ethiopia & 2 & 1 & 1 & & 2 & 6 \\
\hline & Germany $^{\mathrm{a}}$ & & & & 2 & & 2 \\
\hline & France $^{\mathrm{a}}$ & & & & & 1 & 1 \\
\hline & New Zealand ${ }^{\mathrm{a}}$ & & & & & & $\mathbf{0}$ \\
\hline & Colombia & 1 & 1 & & & & 2 \\
\hline & Sub-total & 11 & 5 & 2 & 4 & 9 & 31 \\
\hline \multirow{12}{*}{$\begin{array}{l}\text { Annex I } \\
\text { countries with } \\
\text { the largest } \\
\text { number of } \\
\text { dairy cattle } \\
\text { per capita }\end{array}$} & Ireland & & & & 1 & 2 & 3 \\
\hline & Belarus & & 1 & & & & 1 \\
\hline & Lithuania & & & & 1 & 3 & 4 \\
\hline & Denmark & 1 & 1 & & & 3 & 5 \\
\hline & Netherlands & 1 & & & & 1 & 2 \\
\hline & Latvia & & & & & 1 & $\mathbf{1}$ \\
\hline & Luxembourg & & & & 2 & 2 & 4 \\
\hline & Estonia & & & & 1 & 2 & 3 \\
\hline & Iceland & & & & & & $\mathbf{0}$ \\
\hline & Switzerland & & 1 & & 1 & & 2 \\
\hline & Australia & 4 & 1 & & & 1 & 6 \\
\hline & Sub-total & 6 & 4 & 0 & 6 & 15 & 31 \\
\hline Total number & & 17 & 9 & 2 & 10 & 24 & 62 \\
\hline
\end{tabular}

$274{ }^{a}$ Countries with the highest enteric methane emitting dairy sectors which are also Annex I Parties to the United

275 Nations Framework Convention on Climate Change.

276

277

278

279

280

281

282 
Table 4: A comparison of the number of policies tasked with reducing national dairy sector greenhouse gas emissions as stated by National Communications to the United Nations Framework Convention on Climate Change and other national level policy documents identified from 21 sampled countries. Russia and Sudan are not shown as no English language websites could be located.

\begin{tabular}{|c|c|c|c|c|}
\hline & Country & $\begin{array}{l}\text { Number of policies identified } \\
\text { from policy documents }\end{array}$ & $\begin{array}{l}\text { Number of policies identified } \\
\text { from national communications }\end{array}$ & $\begin{array}{l}\text { Total number of } \\
\text { policies }\end{array}$ \\
\hline \multirow{11}{*}{$\begin{array}{l}\text { Countries } \\
\text { with the } \\
\text { highest enteric } \\
\text { methane } \\
\text { emitting dairy } \\
\text { sectors }\end{array}$} & India & 6 & 0 & 6 \\
\hline & Brazil & 1 & 0 & 1 \\
\hline & $\mathrm{USA}^{\mathrm{a}}$ & 2 & 0 & 2 \\
\hline & China & 0 & 6 & 6 \\
\hline & Pakistan & 5 & 0 & 5 \\
\hline & Ethiopia & 0 & 6 & 6 \\
\hline & Germany $^{\mathrm{a}}$ & 1 & 1 & 2 \\
\hline & France $^{\mathrm{a}}$ & 0 & 1 & $\mathbf{1}$ \\
\hline & New Zealand ${ }^{\mathrm{a}}$ & 0 & 0 & $\mathbf{0}$ \\
\hline & Colombia & 0 & 2 & 2 \\
\hline & Total & 15 & 16 & 31 \\
\hline \multirow{12}{*}{$\begin{array}{l}\text { Annex I } \\
\text { countries with } \\
\text { the largest } \\
\text { number of } \\
\text { dairy cattle } \\
\text { per capita }\end{array}$} & Ireland & 2 & 1 & 3 \\
\hline & Belarus & 0 & 1 & $\mathbf{1}$ \\
\hline & Lithuania & 3 & 1 & 4 \\
\hline & Denmark & 4 & 1 & 5 \\
\hline & Netherlands & 0 & 2 & 2 \\
\hline & Latvia & 1 & 0 & 1 \\
\hline & Luxembourg & 0 & 4 & 4 \\
\hline & Estonia & 3 & 0 & 3 \\
\hline & Iceland & 0 & 0 & $\mathbf{0}$ \\
\hline & Switzerland & 0 & 2 & 2 \\
\hline & Australia & 6 & 0 & 6 \\
\hline & Total & 19 & 12 & 31 \\
\hline \multicolumn{2}{|c|}{ Total number of policies } & 34 & 28 & 62 \\
\hline
\end{tabular}

$287{ }^{a}$ Countries with the highest enteric methane emitting dairy sectors which are also Annex I Parties to the United

288 Nations Framework Convention on Climate Change.

289

290

291

292

293 
Table 5: A comparison of the number policies identified to reduce national dairy sector greenhouse gas 300 emissions from sampled Annex I and non-Annex I countries. Russia and Sudan are not shown as no English 301 language websites could be located.

\begin{tabular}{|c|c|c|c|c|c|c|c|}
\hline & \multirow[t]{2}{*}{ Country } & \multicolumn{5}{|c|}{ Number of policy interventions identified in each theme } & \multirow[t]{2}{*}{ Total number } \\
\hline & & Nutrition & Breeding & Health & Management & Manure & \\
\hline \multirow{16}{*}{$\begin{array}{l}\text { Annex I } \\
\text { countries }\end{array}$} & USA & & & & & 2 & 2 \\
\hline & Germany & & & & 2 & & 2 \\
\hline & France & & & & & 1 & 1 \\
\hline & Belarus & & 1 & & & & 1 \\
\hline & Lithuania & & & & 1 & 3 & 4 \\
\hline & Denmark & 1 & 1 & & & 3 & 5 \\
\hline & Netherlands & 1 & & & & 1 & 2 \\
\hline & Latvia & & & & & 1 & 1 \\
\hline & New Zealand & & & & & & $\mathbf{0}$ \\
\hline & Ireland & & & & 1 & 2 & 3 \\
\hline & Luxembourg & & & & 2 & 2 & 4 \\
\hline & Estonia & & & & 1 & 2 & 3 \\
\hline & Iceland & & & & & & $\mathbf{0}$ \\
\hline & Switzerland & & 1 & & 1 & & 2 \\
\hline & Australia & 4 & 1 & & & 1 & 6 \\
\hline & Sub-total & 6 & 4 & 0 & 8 & 18 & 36 \\
\hline \multirow{7}{*}{$\begin{array}{l}\text { Non-Annex I } \\
\text { countries }\end{array}$} & India & 5 & & & & 1 & 6 \\
\hline & Brazil & & & & & 1 & 1 \\
\hline & China & 1 & 1 & 1 & 2 & 1 & 6 \\
\hline & Pakistan & 2 & 2 & & & 1 & 5 \\
\hline & Ethiopia & 2 & 1 & 1 & & 2 & 6 \\
\hline & Colombia & 1 & 1 & & & & 2 \\
\hline & Sub-total & 11 & 5 & 2 & 2 & 6 & 26 \\
\hline Total number & & 17 & 9 & 2 & 10 & 24 & 62 \\
\hline
\end{tabular}


303 Table 6: The distribution of policies offered by policymakers from 19 countries as dairy sector GHG mitigation strategies. New Zealand and Iceland are not shown as no 304 policies were identified. Russia and Sudan are not shown as no English language websites could be located.

\begin{tabular}{|c|c|c|c|c|c|c|c|c|c|c|c|c|c|c|c|c|c|c|c|c|c|c|c|}
\hline \multirow[t]{2}{*}{ Theme } & \multirow{2}{*}{ Topic } & \multicolumn{9}{|c|}{ Countries with the highest enteric methane emitting dairy sectors } & \multirow{2}{*}{$\begin{array}{l}\text { sub- } \\
\text { total }\end{array}$} & \multicolumn{10}{|c|}{ Annex I countries with the largest number of dairy cattle per capita } & \multirow{2}{*}{$\begin{array}{l}\text { sub- } \\
\text { total }\end{array}$} & \multirow{2}{*}{$\begin{array}{l}\text { Total } \\
\text { number }\end{array}$} \\
\hline & & Ind & Bra & $\mathrm{USA}^{\mathrm{a}}$ & Chi & Pak & Eth & $\mathrm{Ger}^{\mathrm{a}}$ & $\mathrm{Fra}^{\mathrm{a}}$ & $\mathrm{Col}$ & & Ire & Bel & Lit & Den & $\mathrm{Net}$ & Lat & Lux & Est & Swi & Aus & & \\
\hline \multirow[t]{9}{*}{ Nutrition } & Tannin feeding & & & & & & & & & & & & & & & & & & & & 1 & 1 & 1 \\
\hline & Eremophila feeding & & & & & & & & & & & & & & & & & & & & 1 & 1 & $\mathbf{1}$ \\
\hline & Fats/oils feeding & & & & & & & & & & & & & & & & & & & & 1 & 1 & 1 \\
\hline & Nitrate supplements & & & & & & & & & & & & & & & & & & & & 1 & 1 & 1 \\
\hline & Supplement feeding & 1 & & & 1 & & 1 & & & & 3 & & & & & & & & & & & & 3 \\
\hline & Improve digestibility & 1 & & & & & 1 & & & 1 & 3 & & & & & 1 & & & & & & 1 & 4 \\
\hline & Microbe manipulation & 2 & & & & 1 & & & & & 3 & & & & 1 & & & & & & & 1 & 4 \\
\hline & Feed schedule & 1 & & & & & & & & & 1 & & & & & & & & & & & & 1 \\
\hline & Precision Feeding & & & & & 1 & & & & & 1 & & & & & & & & & & & & 1 \\
\hline \multirow[t]{5}{*}{ Manure } & Anaerobic digestion & 1 & & 1 & 1 & 1 & 1 & & 1 & & 6 & 1 & & 1 & 1 & 1 & & 1 & 1 & & 1 & 7 & 13 \\
\hline & $\begin{array}{l}\text { Covering liquid } \\
\text { manure facilities }\end{array}$ & & & 1 & & & & & & & 1 & & & 1 & 1 & & 1 & & 1 & & & 4 & 5 \\
\hline & Slurry Spreading & & & & & & & & & & & 1 & & 1 & & & & 1 & & & & 3 & 3 \\
\hline & Dry spreading & & 1 & & & & 1 & & & & 2 & & & & & & & & & & & & 2 \\
\hline & Cooling slurry & & & & & & & & & & & & & & 1 & & & & & & & 1 & 1 \\
\hline Health & Veterinary Services & & & & 1 & & 1 & & & & 2 & & & & & & & & & & & & 2 \\
\hline \multirow[t]{2}{*}{ Breeding } & High Genetic Merit & & & & 1 & 1 & 1 & & & 1 & 4 & & 1 & & & & & & & 1 & 1 & 3 & 7 \\
\hline & Low emission cow & & & & & 1 & & & & & 1 & & & & 1 & & & & & & & 1 & 2 \\
\hline \multirow[t]{3}{*}{ Management } & Intensification & & & & 1 & & & & & & 1 & 1 & & & & & & & & & & 1 & 2 \\
\hline & Reduced stocking rate & & & & 1 & & & 1 & & & 2 & & & & & & & 1 & & 1 & & 2 & 4 \\
\hline & Organic production & & & & & & & 1 & & & 1 & & & 1 & & & & 1 & 1 & & & 3 & 4 \\
\hline Total number & & 6 & 1 & 2 & 6 & 5 & 6 & 2 & 1 & 2 & 31 & 3 & 1 & 4 & 5 & 2 & 1 & 4 & 3 & 2 & 6 & 31 & 62 \\
\hline
\end{tabular}

\footnotetext{
$305{ }^{a}$ Countries with the highest enteric methane emitting dairy sectors which are also Annex I Parties to the United Nations Framework Convention on Climate Change.

307 Lit=Lithuania, Den=Denmark, Net=the Netherlands, Lat=Latvia, Lux=Luxembourg, Est=Estonia, Swi=Switzerland, Aus=Australia
} 


\section{Discussion}

309 A diverse range of polices were collated from the sampled countries. Such diversity is not

310 unexpected as dairy production takes many forms internationally. Interestingly, the number

311 of policies identified under both sampling strategies was the same (Table 3). However, the

312 preferred theme (Table 3) differed between the high emitting nations and the Annex I nations

313 with the largest number of dairy cattle per capita. Differences in preference at the theme

314 level, reflect the more intensive nature of dairy production in Annex I countries (Table 3).

315 This is clearly illustrated by the comparison of Annex I and non-Annex I nations (Table 5).

316 Annex I countries prefer manure based interventions whilst non-Annex I countries prefer

317 nutrition based interventions.

318 Across the sampled nations, the clustering of interventions around particular themes reveals

319 commonality. For example, manure management techniques are targeted for emission

320 reduction across all nations sampled except Germany, Colombia, Belarus and Switzerland.

321 Targeting manure management for mitigation is a particularly intriguing choice as it is well

322 documented that the majority of dairy sector emissions are a result of enteric fermentation

323 (FAO, 2006, 2010; Gerber et al., 2011; Gerber et al., 2013).

324 The importance of manure emissions as a contributor to dairy sector emissions differs

325 depending on how the manure is managed. Yet, even if manure is managed in liquid form

326 (common to intensive production systems such as; the United States) where the conditions

327 are conducive to methane emission, the total quantity of GHG emitted from the manure is

328 relatively small when compared to enteric emissions. For example, in the United States

329 O'Brien et al. (2014) found that manure methane emissions in an intensive production system

330 were a mere $33 \%$ of enteric methane emissions. The results suggest that policymakers view

331 manure management as an easy target for reduction (compared with enteric sources).

332 However, by not targeting enteric sources it is unlikely that a significant reduction in dairy

333 sector emissions can ever be achieved.

334 Within manure management, policymakers are particularly focused on anaerobic digestion.

335 Anaerobic digestion is likely favoured as it provides multiple benefits (York et al., 2016).

336 However, anaerobic digestion is far from applicable to all types of dairy production. For

337 example, in pasture based systems (such as Australia, and Ireland) manure is excreted

338 directly onto pasture. As a result, only a very small portion of total manure is available for 
digestion. Similarly, traditional manure management practices in India (making of dried dung

340 cakes) are relatively climate change benign (IPCC, 2006; York et al., 2017). Thus, although

341 manure emissions may be viewed as mitigation "low-hanging fruit", the results illustrate a

342 need for policymakers to be aware of the nuanced nature of the dairy sector in its various

343 forms.

344 Nutrition based interventions are also favoured by policymakers, particularly microbe

345 management. Such approaches target the enteric sources responsible for the majority of dairy

346 sector emissions. However, the creation of a low-emission enteric environment is a

347 particularly challenging task. For example, approaches that manipulate rumen microbes (via

348 vaccination against methanogens, defaunation of protozoa, biological control of

349 methanogens, and/or reductive acetogenesis) are far from being commercially available and

350 applicable (Boadi et al., 2004; Eckard et al., 2010; Hristov et al., 2013). Policies based

351 around such technologies will have a significant lag-time between policy

352 development/implementation and realised emission reduction.

353 Interestingly, attempts to reduce dairy sector size are largely ignored by policymakers. Such

354 an omission illustrates the politicalized environment in which policies must exist. The

355 research community is increasingly aware that a reduced sector size may be required for

356 mitigation (see Adler et al., 2013; Doole, 2014; Webb et al., 2014). However, it appears there

357 is little political will to support such a policy across the sampled nations. This is unsurprising

358 in some nations such as India where cattle have a socio-cultural value with restrictions on

359 slaughter. Yet, the broad trend to ignore strategies explicitly aimed at reducing sector size

360 highlights the politically sensitive nature of dairy sector emission mitigation policy as

361 policymakers are required to negotiate embedded societal values. Within India, policies

362 which advocate the use of buffalo (which are generally not afforded the same socio-cultural

363 value as cattle) are an example of the creativity that is required to address politicized policy

364 issues.

365 It could be argued that policy tasked with ensuring intensification and breeding for improved

366 genetic merit are euphemisms for a reduced sector size. Indeed, such terms are likely to

367 receive support from lobby groups and other stakeholders. However, from an emissions

368 perspective, unless productivity improvement is accompanied by a commensurate decrease in

369 total population size it is unlikely sector emissions will be reduced. 
370 The current investigation is not an exhaustive review of national dairy sector policy.

371 Additionally, the study only considered English language documents obtained from internet

372 based resources. This may have created bias as important dairying nations could not be

373 included (e.g. Sudan and Russia). The sorting of policies into themes could also be critiqued

374 for introducing bias due to the need for interpretation (Whittaker, 2009). However, the

375 coupling of this interpretative process with the systematic approach taken toward the

376 literature limits the likely introduction of bias from interpretation as the research can be

377 replicated by others whom would likely arrive at the same conclusions (provided they follow

378 the same protocol).

379 The study sampled only those nations with high levels of dairy sector enteric emissions and

380 Annex I countries with the largest number of dairy cattle per capita. Although this attempted

381 to target those countries which were heavily involved in dairying, important exceptions can

382 be noted. This allowed the contrasting approaches of small and large dairying nations to be

383 examined. For example, Luxembourg has a very small dairy sector. In 2013, Luxembourg

384 had approximately 42000 dairy cattle (FAO, 2013b). As such, policymakers are unlikely to

385 experience pressure from lobby groups which distort the policy process as would be expected

386 in countries with a large dairy sector (such as; United States). The absence of such political

387 pressure appears to allow policymakers to be more progressive in their approach to mitigation

388 as demonstrated by Luxembourg indicating the need for a reduced sector size. This is a stark

389 contrast to New Zealand which is heavily involved in dairy, yet no mitigation policy could be

390 identified. Thus, the role of political will in the development and implementation of

391 mitigation policy within nations that have an economically important (and powerful) dairy

392 sector should not be underestimated. This is concerning as such countries are responsible for

393 a significant portion of the global dairy sector's GHG emissions. The results of this study

394 clearly suggest that policymakers in these nations are unlikely to be proactive or progressive

395 in their approach to reducing dairy sector emissions. As such, the international community

396 may need to consider strategies to influence national dairy sector policy to drive change.

397 The inclusion of National Communications to the UNFCCC may have influenced the final 398 sample of mitigation strategies. Indeed, there is discrepancy in the number of policies

399 identified from policy documents and those reported in National Communications. The

400 purpose of the UNFCCC reports is for each country to outline the steps taken towards

401 emission reduction commitments. However, the results indicate some countries (e.g. India,

402 Pakistan, and Australia) have not been reporting mitigation policies via the National 
403 Communication. Conversely, some nations (e.g. China and Ethiopia) have been reporting the 404 implementation of mitigation without the policies being identified from policy documents.

405 Although the discrepancy may be due to limitations in the search methodology, it may also be 406 an indicator of motivation to conform to international directives (i.e. being seen to be address

407 GHG emissions). Alternatively, it may indicate that some countries are yet to integrate the

408 reports into national policy processes and/or do not have the resources to report achievements

409 via this method. Therefore, it may be necessary for the UNFCCC to reconsider current

410 reporting practices to improve the utility of National Communications as a means of tracking

411 mitigation progress.

412 Although a number of reviews of the available mitigation strategies have been undertaken

413 internationally (e.g. Hristov et al., 2013; Knapp et al., 2014) this investigation is the first

414 attempt at a systematic stocktake of dairy sector GHG emission reduction policy. By taking

415 stock of the current policy environment, it becomes possible to identify the extent to which

416 the burgeoning body of dairy sector emission research has been adopted by policymakers.

\section{5. Conclusion}

418 The study demonstrates manure management (primarily anaerobic digestion) and nutrition

419 based mitigation strategies are favoured by policymakers. Explicit attempts to reduce

420 emissions via manipulation of sector size remain ignored. The final form of the policy

421 landscape cannot be determined from the results of this investigation. Rather, the results

422 highlight the political sensitivity of mitigation policy. Indeed, there is no panacea that will

423 ensure dairy sector emission reduction. However, the trade-offs that policymakers will be

424 required to consider under the guise of climate change compatible development are likely to

425 be significant. It is only by considering the various trade-offs can the long-term sustainability

426 of the sector be secured.

\section{6. Acknowledgements}

428 This work was partly supported by the Harriet Beard Travelling Scholarship from the

429 University of Sydney. 


\section{References}

431 Adler, A.A., Doole, G.J., Romera, A.J., Beukes, P.C., 2013. Cost-effective mitigation of 432 greenhouse gas emissions from different dairy systems in the Waikato region of New 433 Zealand. Journal of Environmental Management 131, 33-43.

434 Boadi, D., Benchaar, C., Chiquette, J., Massé, D., 2004. Mitigation strategies to reduce 435 enteric methane emissions from dairy cows: Update review. Canadian Journal of Animal 436 Science 84, 319-335.

437 Commonwealth of Australia, 2014. Carbon Credits (Carbon Farming Initiative) Amendment 438 Regulations 2014 (No. 1). Commonweath Government of Australia, Canberra, Australia. 439 Doole, G.J., 2014. Least-cost greenhouse gas mitigation on New Zealand dairy farms.

440 Nutrient Cycling in Agroecosystems 98, 235-251.

441 Duffy, B., 2010. The analysis of documentary evidence. In: Bell, J. (Ed.), Doing your 442 Research Project: A guide for first-time researchers in education, health and social science. 443 Open University Press, Maidenhead UK, pp. 124-139.

444 Dutreuil, M., Wattiaux, M., Hardie, C.A., Cabrera, V.E., 2014. Feeding strategies and manure 445 management for cost-effective mitigation of greenhouse gas emissions from dairy farms in 446 Wisconsin. Journal of Dairy Science 97, 5904-5917.

447 Eckard, R.J., Grainger, C., de Klein, C.A.M., 2010. Options for the abatement of methane 448 and nitrous oxide from ruminant production: A review. Livestock Science 130, 47-56.

449 FAO (Ed), 2006. Livestock's Long Shadow: Environmental Issues and Options. Food and 450 Agricultural Organization of the United Nations, Rome, Italy.

451 FAO, 2010. Greenhouse Gas Emissions from the Dairy Sector: A Life Cycle Assessment. 452 Food and Agricultural Organization of the United Nations, Rome, Italy.

453 FAO, 2013a. FAOSTAT Emissions Database. Food and Agricultural Organization of the 454 United Nations.

455 FAO, 2013b. FAOSTAT Population data. Food and Agricultural Organization of the United 456 Nations.

457 Garnaut, R., 2008. Australia's emissions in a global context. In: Garnaut, R. (Ed.), The 458 Garnaut Climate Change Review. Cambridge University Press, Port Melbourne, Australia, 459 pp. 153-171.

460 Gerber, P., Vellinga, T., Opio, C., Steinfeld, H., 2011. Productivity gains and greenhouse gas 461 emissions intensity in dairy systems. Livestock Science 139, 100-108. 
462 Gerber, P.J., Steinfeld, H., Henderson, B., Mottet, A., Opio, C., Dijkman, J., Falcucci, A.,

463 Tempio, G. (Eds.), 2013. Tackling climate change through livestock - A global assessment of

464 emissions and mitigation opportunities. Food and Agriculture Organization of the United

465 Nations, Rome, Italy.

466 Government of India, 2013. National Livestock Policy 2013. Government of India, New

467 Delhi.

468 Heffernan, C., Salman, M., York, L., 2012. Livestock infectious disease and climate change:

469 a review of selected literature. CAB Reviews 7, 1-26.

470 Hristov, A.N., Oh, J., Lee, C., Meinen, R., Montes, F., Ott, T., Firkins, J., Rotz, A., Dell, C.,

471 Adesogan, A., Yang, W., Tricarico, J., Kebreab, E., Waghorn, G., Dijkstra, J., Oosting, S.

472 (Eds.), 2013. Mitigation of greenhouse gas emissions in livestock production - A review of

473 technical options for non-CO2 emissions. Food and Agricultural Organization of the United

474 Nations, Rome, Italy.

475 IPCC, 2006. Emissions from livestock and manure management. In: Eggleston, H.S.,

476 Buendia, L., Miwa, K., Ngara, T., Tanabe, K. (Eds.), 2006 IPCC Guidelines for National

477 Greenhouse Gas Inventories. Prepared by the National Greenhouse Gas Inventories

478 Programme, Intergovernmental Panel on Climate Change, Kamiyamaguchi, Japan, pp. 10.11$479 \quad 10.89$.

480 Knapp, J.R., Laur, G.L., Vadas, P.A., Weiss, W.P., Tricarico, J.M., 2014. Invited review:

481 Enteric methane in dairy cattle production: Quantifying the opportunities and impact of 482 reducing emissions. Journal of Dairy Science 97, 3231-3261.

483 Liberati, A., Altman, D.G., Tetzlaff, J., Mulrow, C., Gøtzsche, P.C., Ioannidis, J.P.A., Clarke, 484 M., Devereaux, P.J., Kleijnen, J., Moher, D., 2009. The PRISMA Statement for Reporting 485 Systematic Reviews and Meta-Analyses of Studies That Evaluate Health Care Interventions: 486 Explanation and Elaboration. PLoS Med 6, e1000100.

487 Ministry of Infrastructure and the Environment, 2013. Sixth Netherlands National

488 Communication under the United Nations Framework Convention on Climate Change.

489 Ministry of Infrastructure and the Environment, The Hague, the Netherlands.

490 Moher, D., Liberati, A., Tetzlaff, J., Altman, D.G., The, P.G., 2009. Preferred Reporting

491 Items for Systematic Reviews and Meta-Analyses: The PRISMA Statement. PLoS Med 6,

492 e1000097.

493 O’Brien, D., Capper, J.L., Garnsworthy, P.C., Grainger, C., Shalloo, L., 2014. A case study

494 of the carbon footprint of milk from high-performing confinement and grass-based dairy

495 farms. Journal of Dairy Science 97, 1835-1851. 
496 Oosting, S.J., Udo, H.M.J., Viets, T.C., 2014. Development of livestock production in the

497 tropics: farm and farmers' perspectives. Animal 8, 1238-1248.

498 Scott, J., 1990. A matter of record: Documentary sources in social research. Polity Press,

499 Padstow UK.

500 The Danish Government, 2013. Climate Policy Plan: Towards a low carbon society. The

501 Danish Government, Copenhagen, Denmark.

502 UNFCCC, 2014a. Glossary of climate change acronyms. United Nations Framework

503 Convention on Climate Change

504 UNFCCC, 2014b. List of Annex I Parties to the Convention. United Nations Framework

505 Convention on Climate Change.

506 UNFCCC, 2014c. Submitted National Communications. United Nations Framework

507 Convention on Climate Change.

508 UNFCCC, 2014d. Submitted National Communications from non-Annex I Parties. United

509 Nations Framework Convention on Climate Change.

510 Webb, J., Audsley, E., Williams, A., Pearn, K., Chatterton, J., 2014. Can UK livestock

511 production be configured to maintain production while meeting targets to reduce emissions of

512 greenhouse gases and ammonia? Journal of Cleaner Production 83, 204-211.

513 Whittaker, A., 2009. Research skills for social work. Learning Matters Ltd., Exeter, UK.

514 Yan, T., Mayne, C.S., Gordon, F.G., Porter, M.G., Agnew, R.E., Patterson, D.C., Ferris, C.P.,

515 Kilpatrick, D.J., 2010. Mitigation of enteric methane emissions through improving efficiency

516 of energy utilization and productivity in lactating dairy cows. Journal of Dairy Science 93,

$517 \quad 2630-2638$.

518 York, L., Heffernan, C., Rymer, C., 2016. The role of subsidy in ensuring the sustainability

519 of small-scale anaerobic digesters in Odisha, India. Renewable Energy 96, 1111-1118.

520 York, L., Heffernan, C., Rymer, C., 2017. A comparison of policies to reduce the methane

521 emission intensity of smallholder dairy production in India. Agriculture, Ecosystems \&

522 Environment 246, 78-85. 